\title{
INACTIVIDAD PARLAMENTARIA Y ACTIVISMO JUDICIAL
}

El actual constitucionalismo imperante en Colombia se ha venido construyendo a lo largo de estos 27 años de vigencia de la Constitución de 1991, gracias a los desarrollos jurisprudenciales de la Corte Constitucional colombiana que, en virtud de su función como defensora de los derechos fundamentales, ha logrado unos importantes avances en esta materia, al punto de crear importantes hitos constitucionales en la historia del país. Muchos de estos pronunciamientos han generado grandes discusiones por su activismo judicial, pues ha creado reglas jurisprudenciales para llenar vacíos legales debido a la inactividad del Congreso colombiano.

Un ejemplo de la anterior afirmación es la reciente decisión de la Corte Constitucional -la SU-096 de 2018que decidió ratificar la despenalización del aborto en tres casos concretos -tomada hace más de 12 años con la sentencia CConst, C-355/2006-, y le dejó al Congreso de la República la tarea de legislar el límite para la interrupción del embarazo, cuestión que muy difícilmente podrá regular y desde ya se puede prever que no pasará nada.

En efecto, en la citada decisión el Alto Tribunal constitucional exhortó al Congreso de la República para que, en ejercicio de su potestad de configuración legislativa, regulara el derecho fundamental a la Interrupción Voluntaria del Embarazo, buscando de esta forma eliminar las barreras aún existentes para el acceso a la IVE. Infortunadamente, el panorama no es muy alentador pues desde ya se puede vaticinar que dicha orden quedará como un saludo a la bandera.

La experiencia ha demostrado que los Honorables Padres de la patria han evadido la responsabilidad de normatizar los temas espinosos del constitucionalismo colombiano. Es por ello que el Alto Tribunal constitucional ha debido tomar decisiones que en ocasiones invaden la competencia del legislador.

El foro natural de la democracia se convirtió en un escenario pasivo que no legisla en asuntos delicados como el aborto, la eutanasia, la dosis personal, el matrimonio de parejas homoparentales, la adopción de menores por homosexuales, etc. Prefieren pasar de agache y dejar vacíos normativos, antes que tomar posturas serias que regulen derechos fundamentales y protejan a los sectores desprotegidos.

Los anteriores magistrados de la Corte Constitucional han "regulado" mediante subreglas jurisprudenciales, temas complejos que han generado controversia pero que a la vez, han solucionado vacíos normativos o problemas de interpretación. Su jurisprudencia hizo avanzar el constitucionalismo colombiano, colocándolo como ejemplo a nivel mundial. No es el camino natural pues para ello existe el Congreso que debería hacer este trabajo, pero ante su pasividad tuvieron que hacer uso de sentencias activistas que en ocasiones le han valido críticas por invadir la esfera del legislativo.

Ahora con los nuevos magistrados que ingresaron hace algunos meses, se cambió la tendencia protectora y activista de la anterior Corte y se está buscando corregir el camino abierto desde hace más de dos décadas, ordenando al parlamento que legisle en materia de corridas de toros y maltrato animal, consultas populares para la actividad minera y limitación del aborto.

Pese a la buena intención de la Corte de reconocerle al Congreso su función legislativa, el panorama es oscuro, pues se sabe que finalmente este no tomará decisiones. El ciudadano deberá seguir acudiendo a la tutela para reclamar sus derechos.

Germán Alfonso López Daza (PhD). 